\title{
ATP Induces a Rapid and Pronounced Increase in 2-Arachidonoylglycerol Production by Astrocytes, a Response Limited by Monoacylglycerol Lipase
}

\author{
Lisa Walter, ${ }^{1}$ Thien Dinh, ${ }^{3}$ and Nephi Stella ${ }^{1,2}$ \\ Departments of ${ }^{1}$ Pharmacology and ${ }^{2}$ Psychiatry and Behavioral Sciences, University of Washington, Seattle, Washington 98195, and ${ }^{3}$ Department of \\ Pharmacology, University of California, Irvine, California 92697
}

\begin{abstract}
The cytoplasm of neural cells contain millimolar amounts of ATP, which flood the extracellular space after injury, activating purinergic receptors expressed by glial cells and increasing gliotransmitter production. These gliotransmitters, which are thought to orchestrate neuroinflammation, remain widely uncharacterized. Recently, we showed that microglial cells produce 2-arachidonoylglycerol (2-AG), an endocannabinoid known to prevent the propagation of harmful neuroinflammation, and that ATP increases this production by threefold at $2.5 \mathrm{~min}$ (Witting et al., 2004). Here we show that ATP increases 2-AG production from mouse astrocytes in culture, a response that is more rapid (i.e., significant within $10 \mathrm{sec}$ ) and pronounced (i.e., 60 -fold increase at $2.5 \mathrm{~min}$ ) than any stimulus-induced increase in endocannabinoid production reported thus far. Increased 2-AG production from astrocytes requires millimolar amounts of ATP, activation of purinergic $\mathrm{P} 2 \mathrm{X}_{7}$ receptors, sustained rise in intracellular calcium, and diacylglycerol lipase activity. Furthermore, we show that astrocytes express monoacylglycerol lipase (MGL), the main hydrolyzing enzyme of 2-AG, the pharmacological inhibition of which potentiates the ATP-induced 2-AG production (up to 113-fold of basal 2-AG production at 2.5 min). Our results show that ATP greatly increases, and MGL limits, 2-AG production from astrocytes. We propose that 2-AG may function as a gliotransmitter, with MGL inhibitors potentiating this production and possibly restraining the propagation of harmful neuroinflammation.
\end{abstract}

Key words: 2-AG; ATP; lipase; cannabinoid; astrocyte; glia

\section{Introduction}

In the CNS, two endocannabinoids have been identified and well characterized: arachidonoylethanolamide (AEA; also known as anandamide) and 2-AG, which activate cannabinoid receptors with distinct pharmacology (Devane et al., 1992; Sugiura et al., 1995; Stella et al., 1997). Recent studies suggest that short-term versus long-term activation of cannabinoid receptors by endocannabinoids induces unique cellular responses. For example, endocannabinoid activation of neuronal $\mathrm{CB}_{1}$ receptors for seconds modulates presynaptic ion channels and inhibits neurotransmitter release (Wilson and Nicoll, 2002), whereas sustained increases in endocannabinoid production and associated activation of cannabinoid receptors for minutes to hours constitutes an "on-demand" defense mechanism limiting cell damage (Marsicano et al., 2003; van der Stelt et al., 2003; Walter and Stella, 2004). In favor of the neuroprotective role of endocannabinoids are studies showing that brain injury leads to a significant in-

Received April 27, 2004; revised June 22, 2004; accepted July 27, 2004.

This work was supported by National Institutes of Health Grant DA14486 (N.S.) and United States Public Health Service National Research Service Award Grant T32 GM07270 from the National Institute of General Medical Sciences (L.W.). We thank Dr. Thomas Möller (NS044337) for access to calcium imaging and Dr. Daniele Piomelli (DA12447) for providing MGL antibody. We also thank Dr. Anke Witting for significant scientific input.

Correspondence should be addressed to Nephi Stella, Department of Pharmacology, University of Washington, 1959 Northeast Pacific Street, Seattle, WA 98195-7280. E-mail: nstella@u.washington.edu.

DOI:10.1523/JNEUROSCI.2419-04.2004

Copyright $\odot 2004$ Society for Neuroscience $\quad 0270-6474 / 04 / 248068-07 \$ 15.00 / 0$ crease in endocannabinoid production (Sugiura et al., 2000, 2001; Panikashvili et al., 2001; Baker et al., 2001; Franklin et al., 2003), improving cell survival after neuronal toxicity induced by kainate, ouabain, closed-head injury, ischemia, and experimental autoimmune encephalomyelitis (Sinor et al., 2000; Baker et al., 2001; Panikashvili et al., 2001; van der Stelt et al., 2001; Parmentier-Batteur et al., 2002; Marsicano et al., 2003). The molecular mechanisms downstream of this protective effect include presynaptic inhibition of glutamate release, decreased release of cytotoxins from resident microglial cells and invading immune cells, increased growth factor expression, and lowering of blood pressure and edema (Waksman et al., 1999; Gallily et al., 2000; Cabral et al., 2001; Kreitzer and Regehr, 2001; ParmentierBatteur et al., 2002; Khaspekov et al., 2004). Whereas the modes of action of endocannabinoids are starting to be understood, their cellular source and the molecular mechanisms controlling their production and inactivation remain unclear.

Endocannabinoid levels are finely tuned by both their production and inactivation. AEA is produced by phospholipase D and hydrolyzed by fatty acid amide hydrolase (FAAH) (Cravatt et al., 2001; Okamoto et al., 2004), and 2-AG is produced by diacylglycerol lipase (DGL) and hydrolyzed by monoacylglycerol lipase (MGL) (Dinh et al., 2002; Bisogno et al., 2003). Many laboratories have reported receptor-mediated increases in endocannabinoid production. To our knowledge the largest and fastest receptor-mediated increase in endocannabinoid production in any cell type has been 
reported in macrophages. Specifically, platelet-activating factor applied for $45 \mathrm{sec}$ increases 2-AG production by 12 -fold in mouse macrophages (Berdyshev et al., 2001). Several reports on the ability of neural cells to produce endocannabinoids are also available. Stimulation of primary rat neurons with glutamate plus carbachol for 2.5 min increases AEA production by 12 -fold and $2-A G$ production by fivefold (Stella and Piomelli, 2001). The same stimulus applied to primary mouse neurons increases AEA production by twofold and 2-AG production by eightfold (Walter et al., 2003). Recently, we showed that ATP increases $2-A G$ production in primary mouse microglial cells, a response that is not significant at $80 \mathrm{sec}$ (N. Stella, unpublished observation), yet reaches a significant threefold increase at $2.5 \mathrm{~min}$ (Witting et al., 2004). Although it is known that astrocytes also produce AEA and 2-AG (Walter et al., 2002; Walter and Stella, 2003), whether ATP affects this production is unknown.

Physiological stimuli lead to synaptic release of ATP in the nanomolar to micromolar range (Edwards and Gibb, 1993), whereas neuropathological conditions associated with cell damage lead to cytoplasmic ATP release in the millimolar range (Dubyak and El-Moatassim, 1993). One pivotal function ascribed to astrocytes is to maintain CNS homeostasis and orchestrate neuroinflammation through their ability to release gliotransmitters (Chen and Swanson, 2003). For example, astrocytes express metabotropic $\mathrm{P} 2 \mathrm{Y}_{1,2,4,6 \& 12}$ and ionotropic $\mathrm{P} 2 \mathrm{X}_{1-7}$ purinergic receptors (James and Butt, 2002; Fumagalli et al., 2003), suggesting that these cells can sense and respond to ATP, and initiate the production of gliotransmitters (John et al., 2001). Because sustained production of endocannabinoids is known to reduce neuroinflammation propagation, and astrocytes produce AEA and 2-AG in a calcium-dependent manner (Walter et al., 2002; Walter and Stella, 2003), we sought to determine the effect of ATP on endocannabinoid production by astrocytes.

\section{Materials and Methods}

Materials. ATP, ADP, AMP, adenosine, adenosine $5^{\prime}$-triphosphate-2' $3^{\prime}$ dialdehyde (oxidized ATP), palmityl trifluoromethyl ketone (PTFMK), phenylmethanesulfonyl fluoride (PMSF), methyl arachidonyl fluorophosphonate (MAFP), EGTA, and all other reagents unless specified otherwise were from Sigma (St. Louis, MO). Pertussis toxin was from Calbiochem (La Jolla, CA). RHC80267 was from Biomol (Plymouth Meeting, PA). Arachidonyl trifluoromethyl ketone (ATFMK) was from Tocris Cookson (Ballwin, MO). Radioactive anandamide and 2-AG were from American Radiolabeled Chemicals (St. Louis, MO).

Cell culture. Mouse astrocytes and neurons in primary cultures were prepared from C57BL/6 mice as described (Walter et al., 2002), according to the guidelines of the Institutional Animal Care and Use Committee of the University of Washington (Seattle, WA). Briefly, 6- to 8-week-old astrocytes prepared from postnatal day 1 mice were plated in DMEM supplemented with $10 \%$ fetal bovine serum (HyClone, Logan, UT) and penicillin-streptomycin $(100 \mathrm{U} / \mathrm{ml}, 100 \mu \mathrm{g} / \mathrm{ml})$ for an additional 1 week and allowed to grow to confluency on 100 and $35 \mathrm{~mm}$ culture dishes (Corning, Corning, NY) and $13 \mathrm{~mm}$ glass coverslips (Fisher Scientific, Houston, TX) in 24-well plates (Corning). One day before use, astrocytes (94\% pure as determined by immunofluorescent glial fibrillary acidic protein labeling) (Walter et al., 2002) were rinsed with PBS with high glucose (33 mM), and media was replaced with serum-free MEM supplemented with L-glutamine (2 mM), HEPES (10 mm), $\mathrm{NaHCO}_{3}(5 \mathrm{~mm})$, and penicillin-streptomycin $(100 \mathrm{U} / \mathrm{ml}$ and $100 \mu \mathrm{g} / \mathrm{ml})$.

Neurons were prepared from day 16 mice embryos using Neurobasal (Invitrogen, San Diego, CA) supplemented with 2\% B27 (Invitrogen), L-glutamate $(0.024 \mathrm{mM})$, L-glutamine $(0.5 \mathrm{~mm})$, and penicillin-streptomycin $(10 \mathrm{U} / \mathrm{ml}$ and $10 \mu \mathrm{g} / \mathrm{ml})$ on $100 \mathrm{~mm}$ dishes 1 week before use (Stella et al., 1995).

Lipid extraction and purification. Endocannabinoids and related lipids from cells plated in $100 \mathrm{~mm}$ dishes were extracted and purified as previously described (Walter et al., 2002; Walter and Stella, 2003). Briefly, cells
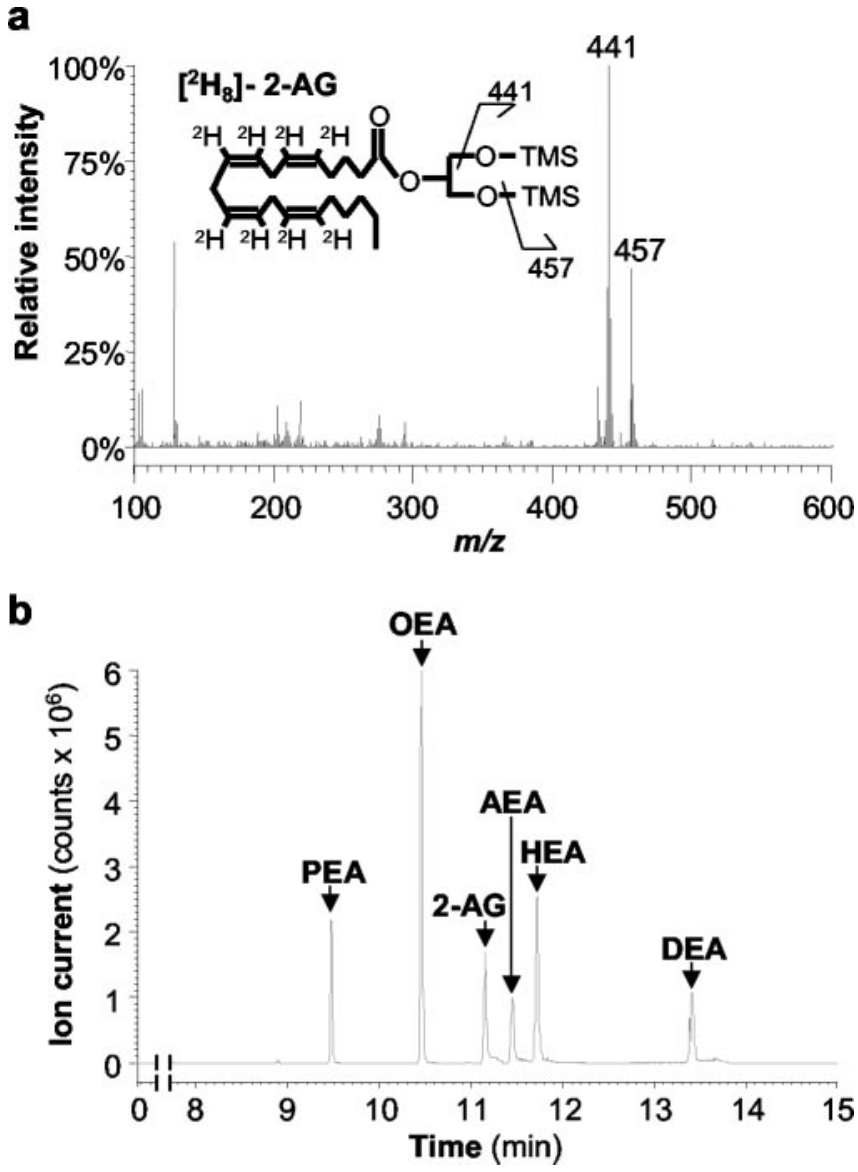

Figure 1. Chemical ionization gas chromatography-mass spectrometry analysis of endocannabinoids and related lipids. $a$, Chemical ionization mass spectrum of $200 \mathrm{pmol}\left[{ }^{2} \mathrm{H}_{8}\right]-2-\mathrm{AG}$ yields a base peak at $m / z=441$. $b$, Two hundred picomoles of: PEA, OEA, 2-AG, AEA, HEA, and DEA were coinjected and monitored by selected ion monitoring, yielding clear separation between peaks.

maintained in $9 \mathrm{ml}$ of culture media $\left(37^{\circ} \mathrm{C}\right)$ were stimulated by adding 1 $\mathrm{ml}$ of media containing drugs prepared at $10 \times$. Stimulations were stopped by adding $10 \mathrm{ml}$ of ice-cold methanol and placing dishes on ice. Total lipids were extracted with $20 \mathrm{ml}$ of chloroform containing six internal standards $\left[200 \mathrm{pmol}\left[{ }^{2} \mathrm{H}_{4}\right]\right.$-AEA, $\left[{ }^{2} \mathrm{H}_{4}\right]$-homo- $\gamma$-linolenoyl ethanolamide (HEA), $\left[{ }^{2} \mathrm{H}_{4}\right]$-docosatetraenoyl ethanolamide (DEA), $\left[{ }^{2} \mathrm{H}_{4}\right]$ oleoyl ethanolamide (OEA), $\left[{ }^{2} \mathrm{H}_{4}\right]$-palmitoyl ethanolamide (PEA), and $\left.\left[{ }^{2} \mathrm{H}_{8}\right]-2-\mathrm{AG}\right]$. Endocannabinoids and related lipids present in organic phases were further purified by open-bed silica gel chromatography followed by HPLC.

Endocannabinoid quantification. Endocannabinoid amounts were quantified by chemical ionization gas chromatography-mass spectrometry (CI GC-MS) as described (Walter et al., 2002; Walter and Stella, 2003), with two important changes.

First, the internal standard used to quantify 2-AG was $\left[{ }^{2} \mathrm{H}_{8}\right]-2-\mathrm{AG}$ instead of $\left[{ }^{2} \mathrm{H}_{4}\right]$-AEA, as previously described (Walter and Stella, 2003). When injected into the GC-MS, $\left[{ }^{2} \mathrm{H}_{8}\right]-2-\mathrm{AG}$ yielded a mass spectrum with the base peak at $m / z=441$, corresponding to the protonated molecule with the neutral loss of one TMS alcohol $\left([\mathrm{M}+\mathrm{H}-90]^{+}\right)$(Fig. 1a). A second major ion was $m / z=457$, resulting from the loss of one TMS group $\left([\mathrm{M}+\mathrm{H}-74]^{+}\right)$(Fig. 1a). We selected the base peak for 2-AG quantification by isotope dilution.

Second, we found that calibration curves generated by directly injecting standards into the GC-MS were different from calibration curves generated with standards added to cell culture media and processed through the HPLC. In particular, the ratio of unlabeled standards to deuterium-labeled standards was higher when measured in media. To be closer to our experimental conditions, we generated calibration curves by 
adding 0,2, 20, and 200 pmol of unlabeled standards and 200 pmol deuterium-labeled standards to $10 \mathrm{ml}$ serum-free MEM and extracted and purified them in the same manner as cells. This allows a more accurate quantification of endocannabinoids and related lipids by correcting possible artifacts caused by sample processing. Using this procedure, we monitored six distinct peaks indicating adequately gas chromatography separation (Fig. 1b). Furthermore, this procedure generated linear calibration curves $\left(r^{2}=0.99-1.00\right)$ and reliable detection limits ( 2 pmol) for each lipid (data not shown).

Values are mean $\pm \mathrm{SE}$ of independent quantifications (amount lipid per milligram of protein), each performed on one $100 \mathrm{~mm}$ dish of cells. Statistical analyses including ANOVA and Student's $t$ test were performed by Prism (Graph Pad Software, San Diego, CA). Protein in $35 \mathrm{~mm}$ dishes of primary astrocytes from the same cell culture preparation was quantified using the DC protein assay (Bio-Rad, Hercules, CA).

Calcium imaging. Calcium imaging was performed as described (Moller et al., 1997). Briefly, astrocytes grown on $13 \mathrm{~mm}$ coverslips placed in 24-well plates were incubated in HEPES-bicarbonate buffer containing fura-2-AM ( $5 \mu \mathrm{M}$; Molecular Probes, Eugene, OR) for $45 \mathrm{~min}$ at room temperature. Cells were placed in a perfusion chamber on an inverted microscope (Diaphot 200; Nikon, New York, NY) equipped with a $40 \times, 1.3$ numerical aperture oil immersion objective. Fura-2 was excited using a Lambda DG-4 filter system (Sutter Instruments, Novato, $\mathrm{CA}$ ) at 340 and $380 \mathrm{~nm}$, and fluorescence emission was collected at $510 \pm$ $20 \mathrm{~nm}$ via a bandpass filter. Fluorescence acquisition and image analysis were performed using a digital imaging system (R3; Inovision, Cleveland, $\mathrm{OH}$ ). Ratios were collected at time intervals of $2 \mathrm{sec}$. To reproduce the experimental conditions used to quantify endocannabinoid production, drugs were added to the chamber under nonperfused conditions.

Reverse-transcription-PCR. Reverse transcription (RT) was performed using superscript first-strand synthesis (Invitrogen). The following mouse MGL primers were used: MGL forward, $5^{\prime}$-CAA GGC CCT CAT CTT TGT GT-3'; and MGL reverse, 5' -ACT TGG AAG TCC GAC ACC AC- $3^{\prime}$. Amplification was performed by 35 cycles of: $94^{\circ} \mathrm{C}$ for $30 \mathrm{sec}$, $61^{\circ} \mathrm{C}$ for $30 \mathrm{sec}$, and $72^{\circ} \mathrm{C}$ for $2 \mathrm{~min}$. Amplification cycles were followed by $72^{\circ} \mathrm{C}$ for $10 \mathrm{~min}$. RT-PCR products were separated on $1.2 \%$ agarose gels, sequenced, and validated by comparison with the National Center for Biotechnology Information database. Absence of RT-PCR product in the "no RT" reaction confirmed the absence of genomic DNA in the samples.

Western blot. Western blot was performed as described (Walter et al., 2003). Briefly, astrocytes and neurons grown in $100 \mathrm{~mm}$ dishes were lysed, and membrane protein fractions were collected after centrifugation at $16,000 \times g$ for $15 \mathrm{~min}$. Samples were electrophoresed (SDSPAGE), transferred to nitrocellulose, and immunoblotted using an antibody directed against rodent MGL with or without the presence of the immunizing peptide.

MGL and FAAH activity. Cells grown in $100 \mathrm{~mm}$ dishes were rinsed with HEPES-bicarbonate buffer, lysed, and homogenized in $50 \mathrm{~mm}$ Tris, $\mathrm{pH}$ 7.5. For each condition, homogenate ( $1 \mathrm{ml}, 35 \mu \mathrm{g}$ protein) was incubated with 75 pm $\left[{ }^{3} \mathrm{H}_{(\mathrm{N})}\right]-2-A G$ for MGL activity or $\left[{ }^{3} \mathrm{H}_{(\mathrm{N})}\right]$-AEA for FAAH activity (American Radiolabeled Chemicals) for 5 min at $37^{\circ} \mathrm{C}$. Reactions were stopped by adding methanol $(1 \mathrm{ml})$, and lipids were extracted with chloroform containing arachidonic acid and 1-AG for MGL activity or AEA for FAAH activity (each at $20 \mu \mathrm{M}$; Cayman Chemicals, Ann Arbor, MI). Samples were separated on silica gel plates (Analtech) using chloroform:methanol:ammonium hydroxide $(80: 20: 1)$ as solvent system. Lipids were visualized with phosphomolybdic acid (10\% in ethanol), bands were scraped off of plates, and radioactivity was determined by scintillation counting. Background radioactivity levels obtained by performing the reaction in the absence of cell homogenate were systematically subtracted.

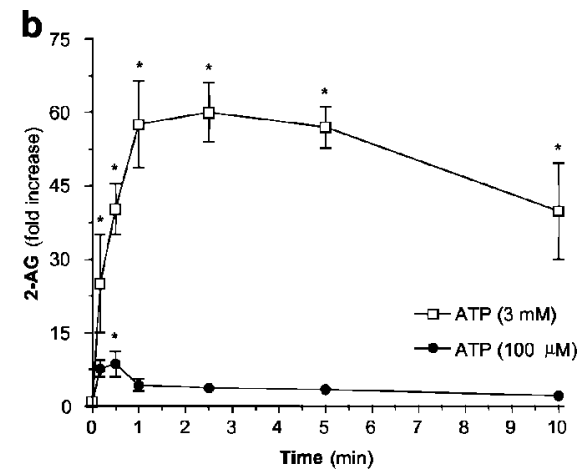

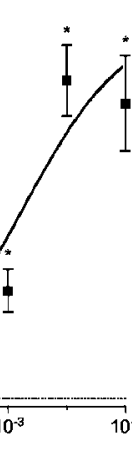

endently increases 2-AG production by mouse astrocytes. Mouse astrocytes in primary culture were treated with culture media (basal levels, dotted line) or ATP at increasing concentrations for 30 $\sec \left(\mathrm{EC}_{50}=1.4 \mathrm{~mm}\right)(a)$ or with ATP at $100 \mu \mathrm{m}$ (closed circles) or $3 \mathrm{~mm}$ (open squares) for indicated times ( $b$ ). Endocannabinoids and related lipids were extracted, purified, and quantified by $\mathrm{Cl}$ GC-MS. Levels of PEA, OEA, AEA, HEA, and DEA were not significantly affected by ATP (data not shown). Basal levels of all endocannabinoids measured did not change significantly at any time points examined (data not shown). *ANOVA followed by Dunnett's post-test; $p<0.05 ; n=4-53$.

\section{Results}

\section{ATP increases 2-AG but not other endocannabinoids in astrocytes}

Quantification of endocannabinoid production by CI GC-MS showed that primary cultures of mouse astrocytes under basal conditions produced $2-\mathrm{AG}$ at $6.88 \pm 0.61 \mathrm{pmol} / \mathrm{mg}$, AEA at $3.1 \pm$ $1.2 \mathrm{pmol} / \mathrm{mg}, \mathrm{HEA}$ at $0.4 \pm 0.2 \mathrm{pmol} / \mathrm{mg}$, DEA at $0.5 \pm 0.2$ $\mathrm{pmol} / \mathrm{mg}$, PEA at $13.4 \pm 3.6 \mathrm{pmol} / \mathrm{mg}$, and OEA at $0.7 \pm 0.1$ $\mathrm{pmol} / \mathrm{mg}(n=35)$, amounts similar to those previously reported (Walter et al., 2002; Walter and Stella, 2003). When astrocytes were treated with increasing concentrations of ATP for $30 \mathrm{sec}$, 2-AG levels increased in a dose-dependent manner (Fig. 2a), whereas levels of other endocannabinoids and related lipids measured were unchanged (data not shown).

We determined the time course of this response, using ATP at two concentrations: $100 \mu \mathrm{M}$, which reflects physiological levels, and $3 \mathrm{~mm}$, which corresponds to the levels reached during injury. At $100 \mu \mathrm{M}$, ATP increased 2-AG production by ninefold at $30 \mathrm{sec}$ (Fig. 2b), which was the only time point with a significant response. At $3 \mathrm{~mm}$, ATP increased 2-AG production 25-fold at 10 $\mathrm{sec}$, a response that reached 60 -fold at $2.5 \mathrm{~min}$ and decreased thereafter (Fig. 2b). To our knowledge, this is the fastest and largest neurotransmitter-induced increase in 2-AG reported for any cell type.

EctoATPases hydrolyze ATP into ADP, AMP, and adenosine, which also elicit cellular responses (Joseph et al., 2003). To rule out the possibility that the effects of ATP on 2-AG were caused by one of its metabolites, endocannabinoid levels were measured in astrocytes treated with ADP, AMP, and adenosine, each at 100 $\mu \mathrm{M}$ for $30 \mathrm{sec}$. No significant change in any lipid levels was observed (data not shown), suggesting that ATP itself increased 2-AG in these cells. Because 2-AG production was maximally increased by $3 \mathrm{~mm}$ of ATP incubated for $2.5 \mathrm{~min}$, we characterized this response further.

\section{ATP increases 2-AG via purinergic $P 2 X 7$ receptors and requires extracellular calcium and diacylglycerol lipase activity}

Two lines of evidence suggest the involvement of $\mathrm{P} 2 \mathrm{X}_{7}$ receptors in the ATP-induced increase in 2-AG production. First, millimolar concentrations of ATP are required to fully induce this response, and $\mathrm{P} 2 \mathrm{X}_{7}$ is the only purinergic receptor subtype requiring millimolar concentration of ATP for activation, $\mathrm{EC}_{50}=780 \mu \mathrm{M}$ 

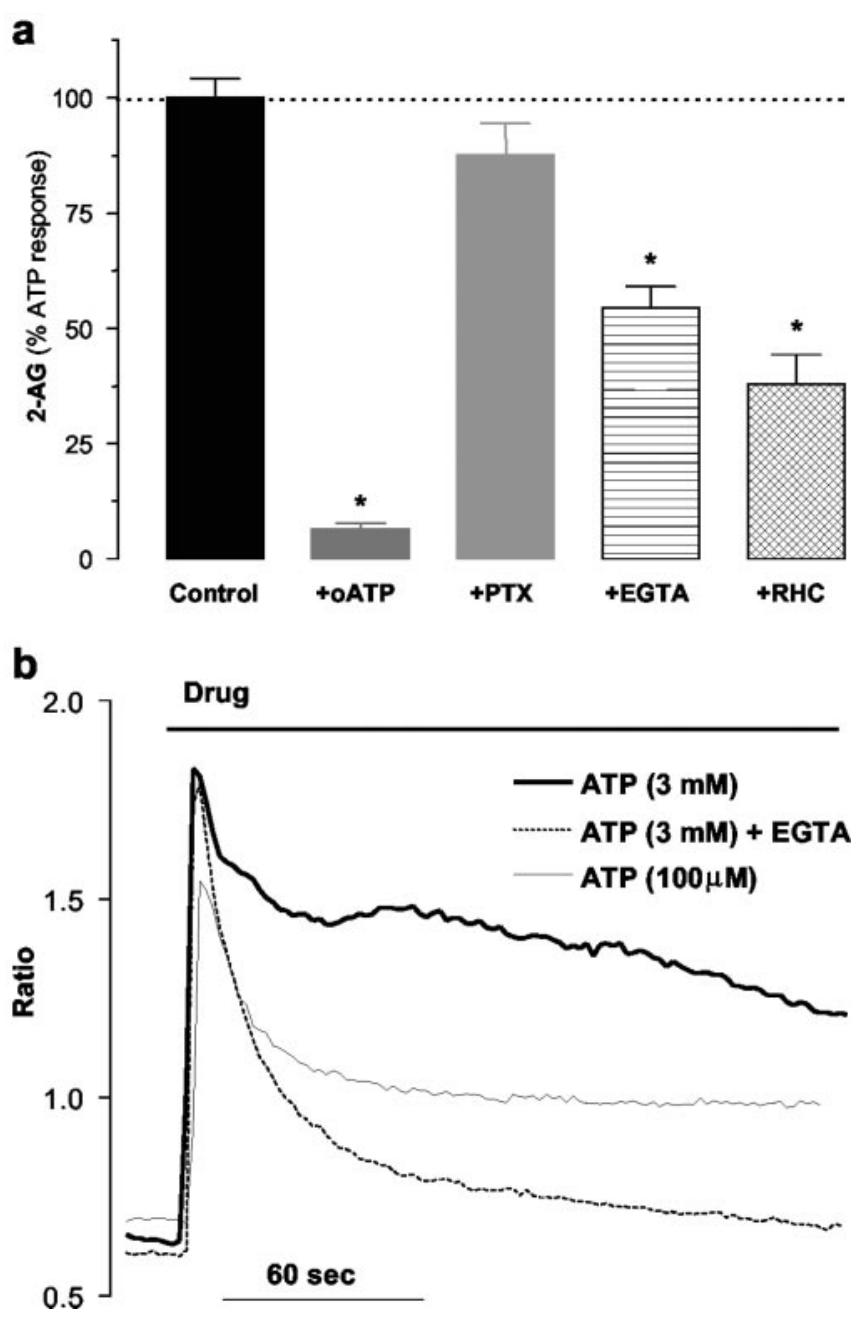

Figure 3. ATP increases $2-A G$ via $P 2 X_{7}$ receptors and requires extracellular calcium and DGL activity. $a$, Primary mouse astrocytes were pretreated with culture media (control), $\mathrm{P} 2 \mathrm{X}_{7}$ antagonist oxidized ATP (oATP, $300 \mu \mathrm{m}$ ) for $2 \mathrm{hr}$, pertussis toxin (PTX, $0.3 \mu \mathrm{g} / \mathrm{ml}$ ) for $4 \mathrm{hr}$, EGTA ( $5 \mathrm{~mm}$ ) for $10 \mathrm{~min}$, or DGL inhibitor RHC80267 (30 $\mu \mathrm{m})$ for 10 min before ATP (3 mm) treatment for 2.5 min. Endocannabinoids and related lipids were extracted, purified, and quantified by $\mathrm{CI} G C-M S$. 2-AG production is expressed as percentage of $3 \mathrm{~mm}$ ATP-induced 2-AG response. *ANOVA followed by Dunnett's post-test; $p<0.05 ; n=5-13 . b$, Primary mouse astrocytes were loaded with fura-2-AM dye to measure intracellular calcium levels. Fluorescence was imaged when cells were treated with ATP (3 mM) in the presence (control) or absence of calcium in the buffer $(+E G T A)$, or with ATP $(100 \mu \mathrm{m})$. Traces are average responses of all the cells in the field of view ( $\sim 30$ cells), representative of $n=3$ separate cultures.

(Chessell et al., 1998). Second, pretreating astrocytes with oxidized ATP, a P2X 7 receptor antagonist (Murgia et al., 1993; Wiley et al., 1994), abolished the $3 \mathrm{~mm}$ ATP-induced 2-AG production (Fig. $3 a$ ). Note that pertussis toxin treatment, which inhibits $G_{i / o}$ proteins, did not alter the effect of $3 \mathrm{~mm}$ ATP-induced 2-AG production (Fig. $3 a$ ), suggesting that $\mathrm{P} 2 \mathrm{Y}$ receptors coupled to $\mathrm{G}_{\mathrm{i} / \mathrm{o}}$ proteins are not involved.

Previous reports indicate that 2-AG production requires extracellular calcium entering cells through ionotropic receptors, which leads to a sustained increase in intracellular calcium $\left(\left[\mathrm{Ca}^{2+}\right]_{i}\right)$ increasing DGL activity (Stella and Piomelli, 2001; Bisogno et al., 2003; Witting et al., 2004). Indeed, preincubation of astrocytes with EGTA, which chelates extracellular calcium and eliminates the $\left[\mathrm{Ca}^{2+}\right]_{i}$ plateau (Fig. $3 b$ ), significantly reduced ATP-induced 2-AG production (Fig. $3 a$ ). ATP at 100 $\mu \mathrm{M}$ also yielded a rapid rise in $\left[\mathrm{Ca}^{2+}\right]_{i}$, but this response was followed by a much lower $\left[\mathrm{Ca}^{2+}\right]_{i}$ plateau (Fig. $3 b$ ), in agreement with the lower increase in $2-A G$ levels compared with ATP at $3 \mathrm{~mm}$ (Fig. 2b).

DGL, an enzyme that has recently been cloned, is known to generate 2-AG by hydrolyzing diacylglycerol (Bisogno et al., 2003). ATP-induced 2-AG production required DGL activity, because the DGL inhibitor RHC80267 significantly reduced this response (Fig. 3a).

\section{Astrocytes express functional MGL}

A rat MGL was recently cloned and shown to be the primary metabolizing enzyme of 2-AG in neurons (Dinh et al., 2002). Three lines of evidence suggest that astrocytes also express MGL. First, using total RNA extracted from cultured astrocytes, we amplified by RT-PCR an amplicon of appropriate size and sequence, suggesting that these cells express mRNA encoding for MGL (Fig. $4 a$ ). Second, using an antibody directed against MGL and Western blot analysis (Dinh et al., 2002), we found that cultured astrocytes express a protein that migrates at $\sim 30 \mathrm{kDa}$, corresponding to the expected size of MGL as shown in neurons (Fig. 4b), suggesting that mouse astrocytes in culture express MGL protein. Third, cell homogenates of cultured astrocytes hydrolyzed 2-AG radioactively labeled on its arachidonic acid moiety into arachidonic acid in a time-dependent manner (Fig. 4d). Addition of increasing concentrations of radioactive $2-\mathrm{AG}(7.5,25,75$, and $250 \mathrm{pm}$ ) led to increased radioactivity in the arachidonic acid fraction (data not shown). This enzymatic activity was inhibited by ATFMK and MAFP, two MGL inhibitors (Dinh et al., 2002), whereas PTFMK and PMSF, two FAAH and PLA2 inhibitors, had no effect (Fig. 4e). In agreement with the noninvolvement of FAAH in this hydrolysis of 2-AG, astrocyte homogenates demonstrated no FAAH activity; i.e., homogenates did not convert AEA into arachidonic acid (Fig. 4c). Finally, MGL activity in homogenates of astrocytes was not significantly affected by ATP, calcium, or EGTA (Fig. 4e), suggesting that this enzyme is not directly regulated by ATP and calcium levels.

\section{Pharmacological control of 2-AG degradation}

To determine if MGL controls 2-AG production, cultured astrocytes were pretreated with a MGL inhibitor, treated with ATP (100 $\mu \mathrm{M}$ or $3 \mathrm{mM}$ ), and endocannabinoid production was determined. In pilot experiments, we found that MGL activity was maximally inhibited by $10 \mu \mathrm{M}$ of either ATFMK or MAFP (data not shown), thus we used these concentrations to examine alterations in endocannabinoid production. Basal 2-AG levels were enhanced by fivefold by ATFMK and by fourfold by MAFP (Fig. $5)$. Although neither inhibitor significantly affected the maximum increase in 2-AG production induced by physiological ( 100 $\mu \mathrm{M}, 30 \mathrm{sec}$ ) and injury-level ATP $(3 \mathrm{~mm}, 2.5 \mathrm{~min})$ (data not shown), both inhibitors augmented the sustained response determined at $10 \mathrm{~min}$, a time point when $2-A G$ production is normally reduced (Fig. 1b). Specifically, ATFMK and MAFP approximately tripled the ATP-induced $(100 \mu \mathrm{M}) 2$-AG levels (from sevenfold to 24-fold and 19-fold, respectively), and approximately doubled the ATP-induced (3 mM) 2-AG levels (from 46-fold to 74-fold and 113-fold, respectively) (Fig. 5). Note that $100 \mu \mathrm{M}$ PTFMK did not affect the ATP (3 mM)-induced 2-AG levels determined at $10 \mathrm{~min}$ (data not shown). Together, these results suggest the decline in ATP-induced 2-AG production observed at $10 \mathrm{~min}$ is caused by MGL activity, and its pharmacological inhibition significantly enhances and prolongs 2-AG production. 


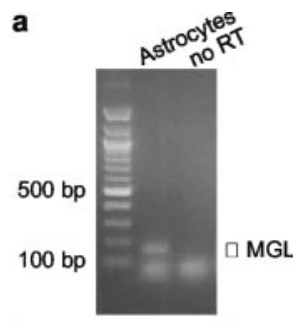

b

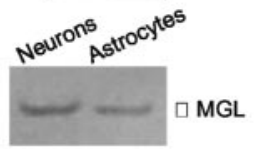

c
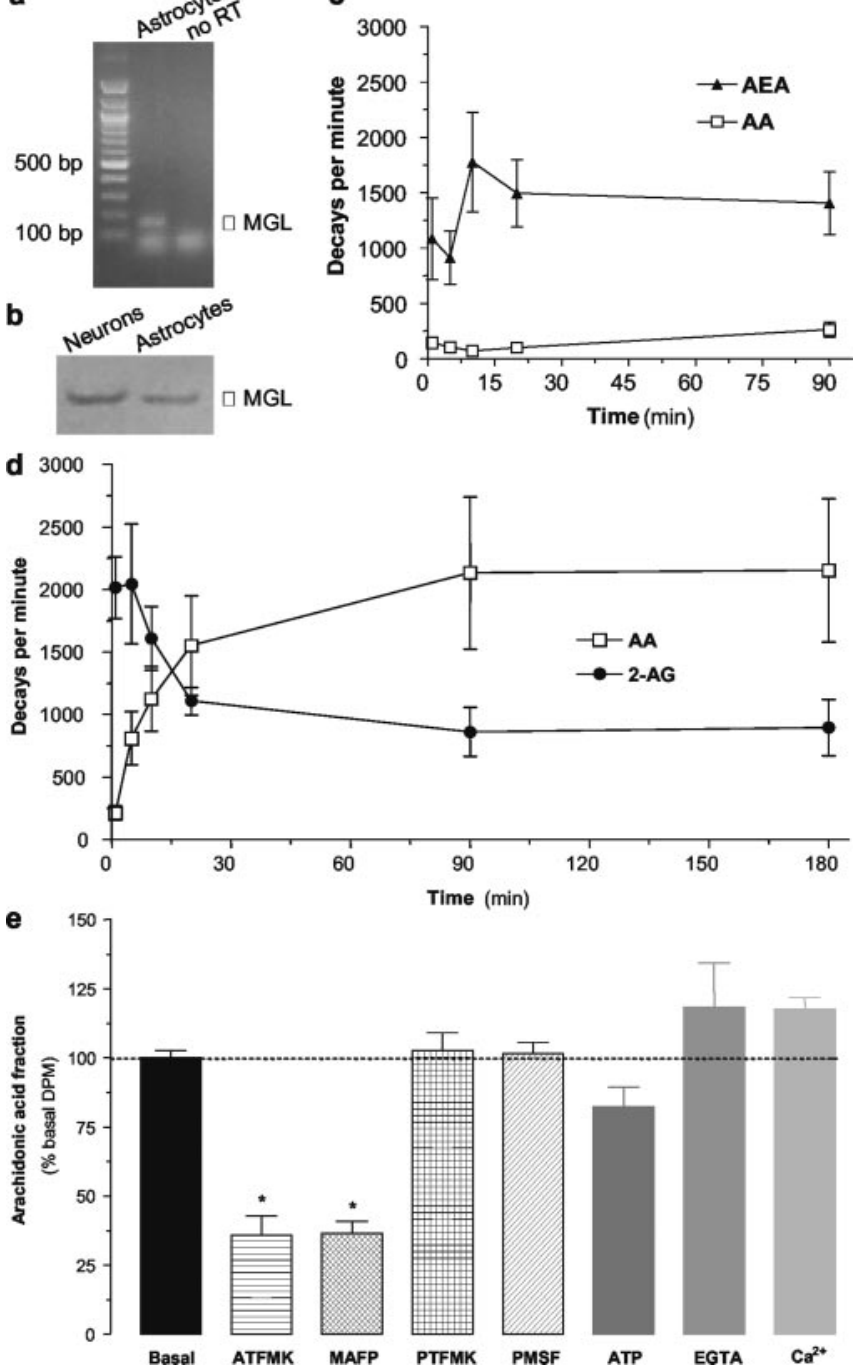

Figure 4. Mouse astrocytes express a functional MGL. $a$, RT-PCR was performed with primers that recognize mouse MGL mRNA. We used reverse-transcribed total RNA from primary mouse astrocytes. RT-PCR products were the appropriate size (162 bp) and sequence. $b$, Western blot revealed that primary mouse neurons and astrocytes express a protein recognized by a MGL antibody at the appropriate size $(\sim 30 \mathrm{kDa})$, representative of $n=3$ separate cultures. Labeling at this size was eliminated when antibody incubation was performed in the presence of immunizing peptide (data not shown). Astrocyte cell homogenates were incubated with $\left[{ }^{3} \mathrm{H}_{(\mathrm{N})}\right]-\mathrm{AEA}$ (c) or $\left[{ }^{3} \mathrm{H}_{(\mathbb{N})}\right]-2-\mathrm{AG}(d)$ for increasing time points at $37^{\circ} \mathrm{C}$. Lipids were chloroform-extracted and analyzed by thin-layer chromatography. Bands with the same retention time as arachidonic acid and AEA $(c)$ or 2-AG $(d)$ were scraped off, and radioactivity was therein determined ( $n=$ 3-6). e, MGL activity, as measured by labeled arachidonic acid production, was significantly inhibited by ATFMK $(10 \mu \mathrm{M})$ and MAFP $(10 \mu \mathrm{M})$, whereas PTFMK $(100 \mu \mathrm{M})$ and PMSF $(100 \mu \mathrm{M})$ had no effect. ATP $(3 \mathrm{~mm})$, EGTA $(5 \mathrm{~mm})$, and extra calcium $\left(\mathrm{CaCl}_{2}, 3 \mathrm{~mm}\right)$ did not affect MGL activity. ${ }^{*}$ ANOVA followed by Dunnett's post-test; $p<0.05 ; n=6-16$.

\section{Discussion}

In this study, we show that ATP increases 2-AG production in mouse astrocytes in primary culture. This response is fast and robust when ATP is applied at injury-level concentrations, occurs via $\mathrm{P} 2 \mathrm{X}_{7}$ receptors, and requires both extracellular calcium and DGL activity. Furthermore, we show that astrocytes express a functional MGL enzyme, the pharmacological inhibition of which further increases and prolongs 2-AG production. To our knowledge, this is the first study reporting that a MGL inhibitor can potentiate receptor-dependent 2-AG production in cells.

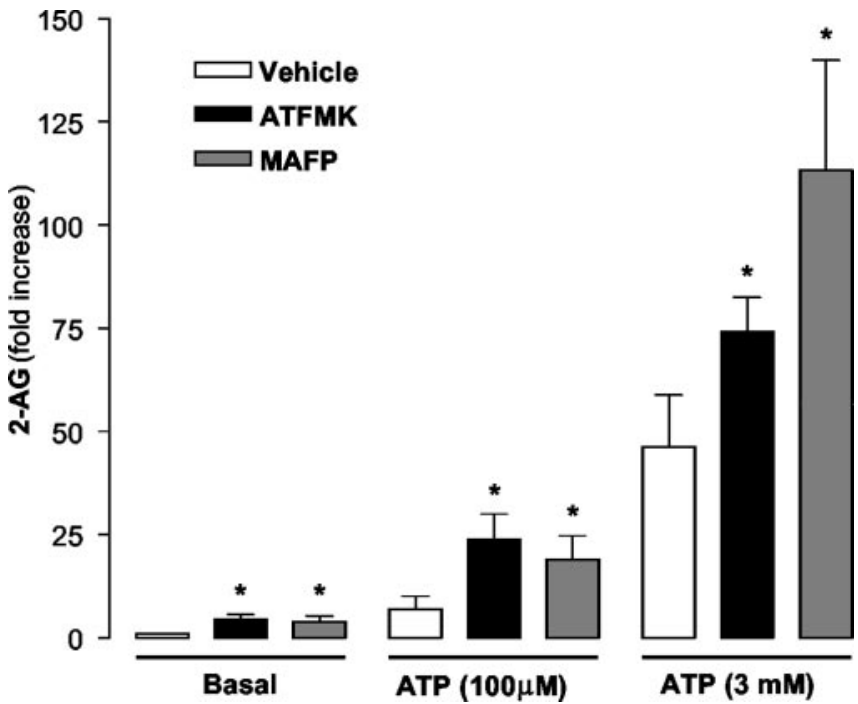

Figure 5. Pharmacological inhibition of MGL increases ATP-induced 2-AG production. Primary mouse astrocytes were pretreated with ATFMK $(10 \mu \mathrm{M})$ or MAFP $(10 \mu \mathrm{M})$ for $10 \mathrm{~min}$ followed by treatment with culture media, $100 \mu \mathrm{m}$ ATP, or $3 \mathrm{~mm}$ ATP (each for $10 \mathrm{~min}$ ). Endocannabinoids and related lipids were extracted, purified, and quantified by $\mathrm{CI}$ GC-MS. 2-AG production is expressed as a percentage of basal 2-AG levels. * Student's $t$ test; $p<0.05 ; n=6-14$.

Amounts of 2-AG in mouse brain are reported to be between 0.5 and $45 \mathrm{pmol} / \mathrm{mg}$ (Baker et al., 2001; Panikashvili et al., 2001; Marsicano et al., 2002; Watanabe et al., 2003; Hanus et al., 2003), and in rat brain between 0.2 and $19 \mathrm{pmol} / \mathrm{mg}$ (Sugiura et al., 1995, 2000, 2001; Stella et al., 1997; Bisogno et al., 1999a,b; Kathuria et al., 2003; Ferrer et al., 2003; Di Marzo et al., 2000; Hansen et al., 2001). Which neural cell type accounts for this production of endocannabinoids? Primary cultures of rat neurons produce $16.5 \pm 3.3 \mathrm{pmol}$ of 2 -AG per milligram of protein (Stella and Piomelli, 2001), whereas primary cultures of mouse neurons only produce $0.4 \pm 0.1 \mathrm{pmol}$ of $2-\mathrm{AG}$ per milligram of protein (Walter et al., 2003). Primary cultures of mouse microglial cells produce $7.0 \pm 0.8 \mathrm{pmol}$ of $2-\mathrm{AG}$ per milligram (Witting et al., 2004). Here we show that astrocytes produce $6.88 \pm 0.61$ pmol of 2-AG per milligram of protein [a previously reported measurement was $\sim 2 \mathrm{pmol} / \mathrm{mg}$ (Walter and Stella, 2003)]. Thus, because astrocytes are the most abundant cell type in the CNS, our results indicate that a substantial portion of 2-AG production in the brain may come from these cells.

Our data reinforce the notion that a sustained rise in $\left[\mathrm{Ca}^{2+}\right]_{i}$ fueled by extracellular calcium is required to increase $2-\mathrm{AG}$ production by cells. Indeed, activation of the $\mathrm{P} 2 \mathrm{X}_{7}$ receptor results in a prolonged opening of its pore, allowing large quantities of extracellular calcium to enter cells (North, 2002). We show that the sustained rise in $\left[\mathrm{Ca}^{2+}\right]_{i}$ induced by $3 \mathrm{~mm}$ of ATP, as well as the increased 2-AG production, are both reduced when EGTA chelates extracellular calcium. Do increases in $2-A G$ production systematically correlate with sustained rises in $\left[\mathrm{Ca}^{2+}\right]_{i}$ ? This seems to be the case. In neurons, activation of NMDA receptors enhances $\left[\mathrm{Ca}^{2+}\right]_{i}$ and increases $2-\mathrm{AG}$ production (Stella and Piomelli, 2001). In macrophage-like cells, both platelet-activating factor and lipopolysaccharide induce sustained increases in $\left[\mathrm{Ca}^{2+}\right]_{i}$ (Khoo et al., 2001; Hoffman et al., 2003) and increase 2-AG production (Berdyshev et al., 2001; Matias et al., 2002). In microglial cells, activation of $\mathrm{P} 2 \mathrm{X}_{7}$ receptors also controls 2-AG production, although this response is much slower and less pronounced (Witting et al., 2004).

Several laboratories have shown that astrocytes inactivate en- 
docannabinoids. However, whether this occurs through FAAH or MGL remained unclear until recently. Neurons account for the majority of FAAH expressed in brain, as assessed by immunohistochemistry; whereas limited expression of FAAH has been reported in astrocytes, suggesting that these cells play a minor role in AEA inactivation. Indeed, compared with liver homogenates, which express high FAAH activity (Cravatt et al., 1996), homogenates from astrocytes in culture hydrolyze little, if any, AEA (Shivachar et al., 1996) (Fig. 4c). Although FAAH has been suggested to participate in 2-AG breakdown in vitro (Goparaju et al., 1998, 1999), this scenario is unlikely to occur in vivo because FAAH knock-out mice have elevated levels of AEA in the CNS (Cravatt et al., 2001), whereas their 2-AG levels remain unchanged (B. Cravatt, personal communication). Furthermore, although PLA2 enzymes have been involved in 2-AG production (Bisogno et al., 1999a,b), and both ATFMK and MAFP are know to inhibit these enzymes (Huang et al., 1996; Lio et al., 1996), we show that PTFMK, a PLA2 enzyme inhibitor, neither affects 2-AG hydrolysis nor augments the ATP-induced 2-AG production, thus ruling out the involvement of these lipases in this response. Thus, our results suggest that astrocytes express MGL, which hydrolyzes 2-AG and finely tunes its production.

The MGL activity in cultured astrocytes differs from that of cultured microglial cells in one important manner: calcium does not affect MGL activity in astrocytes (Fig. 4e), although it inhibits this activity in microglial cells (Witting et al., 2004). Whether this differential sensitivity toward calcium is caused by astrocytes and microglial cells expressing different variants of MGL or different regulating enzymes altogether might account for the differences in kinetics of increased 2-AG production, a topic currently investigated in our laboratory.

In situ, astrocytes express $\mathrm{P}_{2} \mathrm{X}_{7}$ receptors (James and Butt, 2002). Thus, injured neural cells releasing millimolar amounts of ATP might increase 2-AG production from astrocytes as a protective mechanism. Sustained activation of cannabinoid receptors on neurons will inhibit the release of the excitotoxic neurotransmitter glutamate (Shen and Thayer, 1998; Sullivan, 1999). It is also possible that this pronounced production of 2-AG constitutes a means to recruit microglial cells and invading macrophages, because these cells migrate toward 2-AG (Kishimoto et al., 2003; Walter et al., 2003). Because cannabinoids inhibit the release of cytotoxins from microglial cells and invading macrophages and increase their proliferation rate (Waksman et al., 1999; Gallily et al., 2000; Cabral et al., 2001; Carrier et al., 2004), as well as induce growth factor production and reduce edema (Jarai et al., 1999; Marsicano et al., 2003), 2-AG production by astrocytes may aid in slowing or blocking the propagation of neuroinflammation and allied cell damage.

The functions of endocannabinoids in brain are starting to be understood. Here, we suggest that the activity-dependent production of 2-AG by the most prevalent cell type in the CNS may participate in the orchestration of neuroinflammation, possibly by preventing its propagation and harmful effects on neural cells. Pharmacological modulation of the targets involved in endocannabinoid production and degradation may be beneficial for augmenting the neuroprotective properties of the endocannabinoid signaling system.

\section{References}

Baker D, Pryce G, Croxford JL, Brown P, Pertwee RG, Makriyannis A, Khanolkar A, Layward L, Fezza F, Bisogno T, Di Marzo V (2001) Endocannabinoids control spasticity in a multiple sclerosis model. FASEB J 15:300-302.
Berdyshev EV, Schmid PC, Krebsbach RJ, Schmid HH (2001) Activation of PAF receptors results in enhanced synthesis of 2- arachidonoylglycerol (2-AG) in immune cells. FASEB J 15:2171-2178.

Bisogno T, Melck D, De Petrocellis L, Di Marzo V (1999a) Phosphatidic acid as the biosynthetic precursor of the endocannabinoid 2-arachidonoylglycerol in intact mouse neuroblastoma cells with ionomycin. J Neurochem 72:2213-2219.

Bisogno T, Berrendero F, Ambrosino G, Cebeira M, Ramos JA, FernandezRuiz JJ, Di Marzo V (1999b) Brain regional distribution of endocannabinoids: implications for their biosynthesis and biological function. Biochem Biophys Res Commun 256:377-380.

Bisogno T, Howell F, Williams G, Minassi A, Cascio MG, Ligresti A, Matias I, Schiano-Moriello A, Paul P, Williams EJ, Gangadharan U, Hobbs C, Di Marzo V, Doherty P (2003) Cloning of the first sn 1-DAG lipases points to the spatial and temporal regulation of endocannabinoid signaling in the brain. J Cell Biol 163:463-468.

Cabral GA, Harmon KN, Carlisle SJ (2001) Cannabinoid-mediated inhibition of inducible nitric oxide production by rat microglial cells: evidence for CB1 receptor participation. Adv Exp Med Biol 493:207-214.

Carrier EJ, Kearn CS, Barkmeier AJ, Breese NM, Yang W, Nithipatikom K, Pfister SL, Campbell WB, Hillard CJ (2004) Cultured rat microglial cells synthesize the endocannabinoid 2-arachidonylglycerol, which increases proliferation via a $\mathrm{CB}_{2}$ receptor-dependent mechanism. Mol Pharm 65:999-1007.

Chen Y, Swanson RA (2003) Astrocytes and brain injury. J Cereb Blood Flow Metab 23:137-149.

Chessell IP, Michel AD, Humphrey PP (1998) Effects of antagonists at the human recombinant P2X7 receptor. Br J Pharmacol 124:1314-1320.

Cravatt BF, Giang DK, Mayfield SP, Boger DL, Lerner RA, Gilula NB (1996) Molecular characterization of an enzyme that degrades neuromodulatory fatty-acid amides. Nature 384:83-87.

Cravatt BF, Demarest K, Patricelli MP, Bracey MH, Giang DK, Martin BR, Lichtman AH (2001) Supersensitivity to anandamide and enhanced endogenous cannabinoid signaling in mice lacking fatty acid amide hydrolase. Proc Natl Acad Sci USA 98:9371-9376.

Devane WA, Hanus L, Breuer A, Pertwee RG, Stevenson LA, Griffin G, Gibson D, Mandelbaum A, Etinger A, Mechoulam R (1992) Isolation and structure of a brain constituent that binds to the cannabinoid receptor. Science 258:1946-1949.

Di Marzo V, Hill MP, Bisogno T, Crossman AR, Brotchie JM (2000) Enhanced levels of endogenous cannabinoids in the globus pallidus are associated with a reduction in movement in an animal model of Parkinson's disease. FASEB J 14:1432-1438.

Dinh TP, Carpenter D, Leslie FM, Freund TF, Katona I, Sensi SL, Kathuria S, Piomelli D (2002) Brain monoglyceride lipase participating in endocannabinoid inactivation. Proc Natl Acad Sci USA 99:10819-10824.

Dubyak GR, El-Moatassim C (1993) Signal transduction via P2-purinergic receptors for extracellular ATP and other nucleotides. Am J Physiol 265:C577-606.

Edwards FA, Gibb AJ (1993) ATP -a fast neurotransmitter. FEBS Lett 325:86-89.

Ferrer B, Asbrock N, Kathuria S, Piomelli D, Giuffrida A (2003) Effects of levodopa on endocannabinoid levels in rat basal ganglia: implications for the treatment of levodopa-induced dyskinesias. Eur J Neurosci 18:1607-1614.

Franklin A, Parmentier-Batteur S, Walter L, Greenberg DA, Stella N (2003) Palmitoylethanolamide increases after focal cerebral ischemia and potentiates microglial cell motility. J Neurosci 23:7767-7775.

Fumagalli M, Brambilla R, D’Ambrosi N, Volonte C, Matteoli M, Verderio C, Abbracchio MP (2003) Nucleotide-mediated calcium signaling in rat cortical astrocytes: role of P2X and P2Y receptors. Glia 43:218-230.

Gallily R, Breuer A, Mechoulam R (2000) 2-Arachidonylglycerol, an endogenous cannabinoid, inhibits tumor necrosis factor-alpha production in murine macrophages, and in mice. Eur J Pharmacol 406:5-7.

Goparaju SK, Ueda N, Yamaguchi H, Yamamoto S (1998) Anandamide amidohydrolase reacting with 2-arachidonoylglycerol, another cannabinoid receptor ligand. FEBS Lett 422:69-73.

Goparaju SK, Ueda N, Taniguchi K, Yamamoto S (1999) Enzymes of porcine brain hydrolyzing 2-arachidonoylglycerol, an endogenous ligand of cannabinoid receptors. Biochem Pharmacol 57:417-423.

Hansen HH, Schmid PC, Bittigau P, Lastres-Becker I, Berrendero F, Manzanares J, Ikonomidou C, Schmid HH, Fernandez-Ruiz JJ, Hansen HS (2001) Anandamide, but not 2-arachidonoylglycerol, accumulates during in vivo neurodegeneration. J Neurochem 78:1415-1427.

Hanus L, Avraham Y, Ben-Shushan D, Zolotarev O, Berry EM, Mechoulam R 
(2003) Short-term fasting and prolonged semistarvation have opposite effects on 2-AG levels in mouse brain. Brain Res 983:144-151.

Hoffman A, Kann O, Ohlemeyer C, Hanisch UK, Kettenmann H (2003) Elevation of basal intracellular calcium as a central element in the activation of brain macrophages (microglia): suppression of receptor-evoked calcium signaling and control of release function. J Neurosci 23:4410-4419.

Huang Z, Payette P, Abdullah K, Cromlish WA, Kennedy BP (1996) Functional identification of the active-site nucleophile of the human $85-\mathrm{kDa}$ cytosolic phospholipase A2. Biochemistry 35:3712-3721.

James G, Butt AM (2002) P2Y and P2X purinoceptor mediated $\mathrm{Ca}(2+)$ signalling in glial cell pathology in the central nervous system. Eur J Pharmacol 447:247-260.

Jarai Z, Wagner JA, Varga K, Lake KD, Compton DR, Martin BR, Zimmer AM, Bonner TI, Buckley NE, Mezey E, Razdan RK, Zimmer A, Kunos G (1999) Cannabinoid-induced mesenteric vasodilation through an endothelial site distinct from CB1 or CB2 receptors. Proc Natl Acad Sci USA 96:14136-14141.

John GR, Simpson JE, Woodroofe MN, Lee SC, Brosnan CF (2001) Extracellular nucleotides differentially regulate interleukin-1beta signaling in primary human astrocytes: implications for inflammatory gene expression. J Neurosci 21:4134-4142.

Joseph SM, Buchakjian MR, Dubyak GR (2003) Colocalization of ATP release sites and ecto-ATPase activity at the extracellular surface of human astrocytes. J Biol Chem 278:23331-23342.

Kathuria S, Gaetani S, Fegley D, Valino F, Duranti A, Tontini A, Mor M, Tarzia G, La Rana G, Calignano A, Giustino A, Tattoli M, Palmery M, Cuomo V, Piomelli D (2003) Modulation of anxiety through blockade of anandamide hydrolysis. Nat Med 9:76-81.

Khaspekov LG, Brenz Verca MS, Frumkina LE, Hermann H, Marsicano G, Lutz B (2004) Involvement of brain-derived neurotrophic factor in cannabinoid receptor-dependent protection against excitotoxicity. Eur J Neurosci 19:1691-1698.

Khoo C, Helm J, Choi HB, Kim SU, McLarnon JG (2001) Inhibition of store-operated $\mathrm{Ca}(2+)$ influx by acidic extracellular $\mathrm{pH}$ in cultured human microglia. Glia 36:22-30.

Kishimoto S, Gokoh M, Oka S, Muramatsu M, Kajiwara T, Waku K, Sugiura $\mathrm{T}$ (2003) 2-arachidonoylglycerol induces the migration of HL-60 cells differentiated into macrophage-like cells and human peripheral blood monocytes through the cannabinoid CB2 receptor-dependent mechanism. J Biol Chem 278:24469-24475.

Kreitzer AC, Regehr WG (2001) Retrograde inhibition of presynaptic calcium influx by endogenous cannabinoids at excitatory synapses onto Purkinje cells. Neuron 29:717-727.

Lio YC, Reynolds LJ, Balsinde J, Dennis EA (1996) Irreversible inhibition of $\mathrm{Ca}(2+)$-independent phospholipase A2 by methyl arachidonyl fluorophosphonate. Biochim Biophys Acta 1302:55-60.

Marsicano G, Wotjak CT, Azad SC, Bisogno T, Rammes G, Cascio MG, Hermann H, Tang J, Hofmann C, Zieglgansberger W, Di Marzo V, Lutz B (2002) The endogenous cannabinoid system controls extinction of aversive memories. Nature 418:530-534.

Marsicano G, Goodenough S, Monory K, Hermann H, Eder M, Cannich A, Azad SC, Cascio MG, Gutierrez SO, van der Stelt M, Lopez-Rodriguez ML, Casanova E, Schutz G, Zieglgansberger W, Di Marzo V, Behl C, Lutz B (2003) CB1 cannabinoid receptors and on-demand defense against excitotoxicity. Science 302:84-88.

Matias I, Pochard P, Orlando P, Salzet M, Pestel J, Di Marzo V (2002) Presence and regulation of the endocannabinoid system in human dendritic cells. Eur J Biochem 269:3771-3778.

Moller T, Nolte C, Burger R, Verkhratsky A, Kettenmann H (1997) Mechanisms of $\mathrm{C} 5 \mathrm{a}$ and $\mathrm{C} 3 \mathrm{a}$ complement fragment-induced $[\mathrm{Ca} 2+]$ i signaling in mouse microglia. J Neurosci 17:615-624.

Murgia M, Hanau S, Pizzo P, Rippa M, Di Virgilio F (1993) Oxidized ATP. An irreversible inhibitor of the macrophage purinergic $\mathrm{P} 2 \mathrm{Z}$ receptor. J Biol Chem 268:8199-8203.

North RA (2002) Molecular physiology of P2X receptors. Physiol Rev 82:1013-1067.

Okamoto Y, Morishita J, Tsuboi K, Tonai T, Ueda N (2004) Molecular characterization of a phospholipase D generating anandamide and its congeners. J Biol Chem 279:5298-5305.
Panikashvili D, Simeonidou C, Ben-Shabat S, Hanus L, Breuer A, Mechoulam $\mathrm{R}$, Shohami E (2001) An endogenous cannabinoid (2-AG) is neuroprotective after brain injury. Nature 413:527-531.

Parmentier-Batteur S, Jin K, Mao XO, Xie L, Greenberg DA (2002) Increased severity of stroke in $\mathrm{CB} 1$ cannabinoid receptor knock-out mice. J Neurosci 22:9771-9775.

Shen M, Thayer SA (1998) Cannabinoid receptor agonists protect cultured rat hippocampal neurons from excitotoxicity. Mol Pharmacol 54:459-462.

Shivachar AC, Martin BR, Ellis EF (1996) Anandamide- and delta9tetrahydrocannabinol-evoked arachidonic acid mobilization and blockade by SR141716A [N-(Piperidin-1-yl)-5-(4-chlorophenyl)-1-(2,4dichlorophenyl)-4 -methyl-1H-pyrazole-3- carboximide hydrochloride]. Biochem Pharmacol 51:669-676.

Sinor AD, Irvin SM, Greenberg DA (2000) Endocannabinoids protect cerebral cortical neurons from in vitro ischemia in rats. Neurosci Lett 278:157-160.

Stella N, Piomelli D (2001) Receptor-dependent formation of endogenous cannabinoids in cortical neurons. Eur J Pharmacol 425:189-196.

Stella N, Pellerin L, Magistretti PJ (1995) Modulation of the glutamateevoked release of arachidonic acid from mouse cortical neurons: involvement of a pH-sensitive membrane phospholipase A2. J Neurosci 15:3307-3317.

Stella N, Schweitzer P, Piomelli D (1997) A second endogenous cannabinoid that modulates long-term potentiation. Nature 388:773-778.

Sugiura T, Kondo S, Sukagawa A, Nakane S, Shinoda A, Itoh K, Yamashita A, Waku K (1995) 2-Arachidonoylglycerol: a possible endogenous cannabinoid receptor ligand in brain. Biochem Biophys Res Commun 215:89-97.

Sugiura T, Yoshinaga N, Kondo S, Waku K, Ishima Y (2000) Generation of 2 -arachidonoylglycerol, an endogenous cannabinoid receptor ligand, in picrotoxinin-administered rat brain. Biochem Biophys Res Commun 271:654-658.

Sugiura T, Yoshinaga N, Waku K (2001) Rapid generation of 2-arachidonoylglycerol, an endogenous cannabinoid receptor ligand, in rat brain after decapitation. Neurosci Lett 297:175-178.

Sullivan JM (1999) Mechanisms of cannabinoid-receptor-mediated inhibition of synaptic transmission in cultured hippocampal pyramidal neurons. J Neurophysiol 82:1286-1294.

van der Stelt M, Veldhuis WB, van Haaften GW, Fezza F, Bisogno T, Bar PR, Veldink GA, Vliegenthart JF, Di Marzo V, Nicolay K (2001) Exogenous anandamide protects rat brain against acute neuronal injury in vivo. J Neurosci 21:8765-8771.

van der Stelt M, Hansen HH, Veldhuis WB, Bar PR, Nicolay K, Veldink GA, Vliegenthart JFG, Hansen HS (2003) Biosynthesis of endocannabinoids and their modes of action in neurodegenerative diseases. Neurotox Res 5:183-200.

Waksman Y, Olson JM, Carlisle SJ, Cabral GA (1999) The central cannabinoid receptor (CB1) mediates inhibition of nitric oxide production by rat microglial cells. J Pharmacol Exp Ther 288:1357-1366.

Walter L, Stella N (2003) Endothelin-1 increases 2-arachidonoyl glycerol (2-AG) production in astrocytes. Glia 44:85-90.

Walter L, Stella N (2004) Cannabinoids and neuroinflammation. Br J Pharmacol 141:775-785.

Walter L, Franklin A, Witting A, Moller T, Stella N (2002) Astrocytes in culture produce anandamide and other acylethanolamides. J Biol Chem 26:26.

Walter L, Franklin A, Witting A, Wade C, Xie Y, Kunos G, Mackie K, Stella N (2003) Nonpsychotropic cannabinoid receptors regulate microglial cell migration. J Neurosci 23:1398-1405.

Watanabe S, Doshi M, Hamazaki T (2003) n-3 Polyunsaturated fatty acid (PUFA) deficiency elevates and n-3 PUFA enrichment reduces brain 2-arachidonoylglycerol level in mice. Prostaglandins Leukot Essent Fatty Acids 69:51-59.

Wiley JS, Chen JR, Snook MB, Jamieson GP (1994) The P2Z-purinoceptor of human lymphocytes: actions of nucleotide agonists and irreversible inhibition by oxidized ATP. Br J Pharmacol 112:946-950.

Wilson RI, Nicoll RA (2002) Endocannabinoid signaling in the brain. Science 296:678-682.

Witting A, Walter L, Wacker J, Moller T, Stella N (2004) P2X7 receptors control 2-arachidonoylglycerol production by microglial cells. Proc Natl Acad Sci USA 101:3214-3219. 